\title{
Potential adverse effects on animal health and performance caused by the addition of mineral adsorbents to feeds to reduce mycotoxin exposure
}

\author{
Christopher T. Elliott ${ }^{1}$ (D) $\cdot$ Lisa Connolly ${ }^{1} \cdot$ Oluwatobi Kolawole $^{1}$ \\ Received: 27 May 2019 /Revised: 2 September 2019 / Accepted: 4 September 2019 / Published online: 13 September 2019 \\ (C) The Author(s) 2019
}

\begin{abstract}
The contamination of feed with mycotoxins is a continuing feed quality and safety issue, leading to significant losses in livestock production and potential human health risks. Consequently, various methods have been developed to reduce the occurrence of mycotoxins in feed; however, feed supplementation with clay minerals or mineral adsorbents is the most prominent approach widely practiced by farmers and the feed industry. Due to a negatively charged and high surface area, pore volume, swelling ability, and high cation exchange capacity, mineral adsorbents including bentonite, zeolite, montmorillonite, and hydrated sodium calcium aluminosilicate can bind or adsorb mycotoxins to their interlayer spaces, external surface, and edges. Several studies have shown these substances to be partly or fully effective in counteracting toxic effects of mycotoxins in farm animals fed contaminated diets and thus are extensively used in livestock production to reduce the risk of mycotoxin exposure. Nevertheless, a considerable number of studies have indicated that these agents may also cause undesirable effects in farm animals. The current work aims to review published reports regarding adverse effects that may arise in farm animals (with a focus on pig and poultry) and potential interaction with veterinary substances and nutrients in feeds, when mineral adsorbents are utilized as a technological feed additive. Furthermore, results of in vitro toxicity studies of both natural and modified mineral adsorbents on different cell lines are reported. Supplementation of mycotoxin-contaminated feed with mineral adsorbents must be carefully considered by farmers and feed industry.
\end{abstract}

Keywords Mycotoxins $\cdot$ Mineral adsorbents $\cdot$ Toxicity $\cdot$ Health effects $\cdot$ Feed safety

$\begin{array}{ll}\text { Abbreviations } \\ \text { VTMS } & \text { Vinyltrimethoxysilane } \\ \text { HDTM } & \text { Hexadecyltrimethyl } \\ \text { BAC } & \text { Benzalkonium chloride } \\ \text { CMAB } & \text { Cetyltrimethylammonium bromide } \\ \text { OBAC } & \text { Octadecyldimethyl benzyl ammonium chloride } \\ \text { ACO } & \text { Acetylcholine chloride } \\ \text { HDA } & \text { Hexadecylamine } \\ \text { CHO } & \text { Chinese hamster ovary } \\ \text { HDTMA } & \text { Hexadecyltrimethylammonium } \\ \text { CBMN } & \text { Cytokinesis block micronucleus cytome }\end{array}$

Christopher T. Elliott

Chris.Elliott@qub.ac.uk

1 Institute for Global Food Security, School of Biological Sciences, Queens University Belfast, Belfast, UK
HSCAS Hydrated sodium calcium aluminosilicates

\section{Introduction}

Feed is an integral part of the food chain, and it plays an important role in the growth, welfare, and productivity of farm animal as well as in the composition, safety, and quality of livestock products (milk, meat, and eggs) in the food supply chain (Guerre 2016; Makkar 2016). A complete or finished feed is manufactured from a mixture of raw materials of plant, animal, industrial, and pharmaceutical origin, and formulated to achieve a range of objectives in animals regarding health and performance (Ittiphalin et al. 2015; Guerre 2016). A recent global feed survey shows world compound feed production has reached 1.1 billion metric tons; China, USA, Brazil, Russia, India, Mexico, Spain, and Turkey represent the top eight countries responsible for $55 \%$ of total global feed 
production (Alltech 2019). Furthermore, commercial production of animal feeds takes place in 144 countries and generates an annual turnover of more than US\$400 billion (IFIF 2018). This is expected to increase, as the industry is under pressure to increase the amount of safe and nutritious feed, to meet the global demand for livestock products (Makkar and Ankers 2014). However, one of the greatest challenges facing farmers and the feed industry is the occurrence of mycotoxins in feed ingredients (Li et al. 2014; Pinotti et al. 2016). Mycotoxins in feed are a potential risk for animal performance, health, and the safety of foods of animal origin. More than 400 mycotoxins have been identified; however, only few have attracted scientific and regulatory interest due to the huge difficulties of collecting sufficient data in terms of frequency of occurrence and toxicity. The regulated mycotoxins in many parts of the world include aflatoxin $\mathrm{B} 1\left(\mathrm{AFB}_{1}\right)$, deoxynivalenol (DON), ochratoxin A (OTA), zearalenone (ZEN), fumonisin B1 $\left(\mathrm{FB}_{1}\right)$, and trichothecenes A- (T-2 and HT-2) (Zain 2011). These mycotoxins are produced by Aspergillus, Fusarium, and Penicillium species (Sweeney 1998) and their production is influenced by factors such as agronomic practice, pre- and post-harvest climate conditions (temperature, moisture level and carbon dioxide) (Pitt and Miller 2016; Gilbert et al. 2017). Hence, contamination can occur during crop growth, storage, and transportation (Mannaa and Kim 2017).

A number of mycotoxins surveys have been carried out to investigate the worldwide occurrence of mycotoxins in feed materials such as wheat, maize, soybean meal, and dried distillers' grains (Monbaliu et al. 2010; Rodrigues and Naehrer 2012; Streit et al. 2013; Kosicki et al. 2016). The toxic effects of mycotoxin on animal health is termed mycotoxicosis, the degree of toxicity depends on the type of mycotoxins, level ingested, exposure time, breed, age, sex, health status of animal, and other stress factors (Zaki 2012; Khatoon 2016; Ostry et al. 2016; Dellafiora and Dall'Asta 2017). To counteract mycotoxicosis in farm animals, the European Commission (EC) regulation on additives for use in animal nutrition was amended and a new regulation (EC No 386/2009) in the category of technological feed additives defines a new functional group of feed additives as "substances for reduction of the contamination of feed by mycotoxins: substances that can suppress or reduce the absorption, promote the excretion of mycotoxins or modify their mode of action." (EC 2009). Consequently, several research groups have examined the potential of mineral adsorbents to bind mycotoxins in vitro, and their protective effects against mycotoxicosis in vivo. The topic has been extensively reviewed by Huwig et al. (2001), Döll and Dänicke (2004), Avantaggiato et al. (2005), Kolosova and Stroka (2011), Di Gregorio et al. (2014), Zhu et al. (2016), Wielogórska et al. (2016), Peng et al. (2018), and Vila-Donat et al. (2018); a summary of recent studies (2014-2019) carried out on the efficacy of mineral adsorbents to alleviate mycotoxicosis in broiler chicken is shown in Table 1. Data on mycotoxin adsorption by mineral adsorbents with other animal species during the time period are scarce in the scientific literature. Other studies have also shown that mineral adsorbents may not be effective and can induce deleterious effects in farm animals when supplemented with feeds (Dwyer et al. 1997; Watts et al. 2003. Döll and Dänicke 2004; Lemke et al. 2001; Khatoon et al. 2018). As these agents are naturally abundant, inexpensive, and can be chemically modified to further increase mycotoxin-adsorption capacity, leading to an extensive use in livestock feeding, this review aims to highlight adverse effects in farm animals caused by the supplementation of animal feeds with mineral adsorbents and consequences of their interaction with veterinary substances and micronutrients in feeds.

\section{Composition and structure of clay minerals}

Clays are fine graded (average particle size $<0.002 \mathrm{~mm}$ ) natural rock or soil material that exhibit plasticity when moistened or non-plastic and hard when dried (Andrade et al. 2011). Aluminosilicates are the largest and most important class of clay minerals, composed of silica, alumina, and significant amounts of alkaline and alkaline earth ions (Moreno-Maroto and Alonso-Azcárate 2018). Within this class, phyllosilicates and tectosilicates have received much scientific attention because they have a wide range of applications (Srinivasan 2011; Ghadiri et al. 2015).

The basic structure of phyllosilicates is based on tetrahedral sheets $(\mathrm{T})$ composed of individual tetrahedrons which share three out of four oxygens, and octahedral sheets $(\mathrm{O})$ composed of individual octahedrons that share apical oxygen and hydroxyl anion groups with cations such as aluminum and magnesium. The stacking of both sheets determines the chemistry and crystallography of each phyllosilicate. The T-O ratio of layer structure is used to classify phyllosilicates into 1:1 (T-O) and 2:1 (T-O-T) (Wang et al. 2015). Example of phyllosilicates include montmorillonite, illites, bentonite, and kaolinite. Tectosilicate have a three-dimensional framework structure wherein all the four oxygens of tetrahedron are shared with other tetrahedra (Alaniz et al. 2012); thus, the T-O ratio is 1:2. Examples of tectosilicates include zeolite, quarts, and feldspar. A summary of main clay minerals or mineral adsorbents currently used for sequestering mycotoxins is shown in Table 2.

Although phyllosilicates and tectosilicates are composed of $\mathrm{O}$ and $\mathrm{T}$ sheets as predominant building blocks, the physicochemical properties of these minerals including charge, polarity, expandability, cation exchange capacity (CEC), $\mathrm{pH}$, particle size, surface area, swelling ability, and adsorption capacity are dependent on structure, composition, and geographical origin (Deepthy and Balakrishnan 2005; Ito and Wagai 2017). In terms of natural abundance, a large percentage of mineral adsorbents are found mostly in twenty-three 
Table 1 In vivo studies on the adsorption of mycotoxins in broiler chicken fed contaminated diet

\begin{tabular}{|c|c|c|c|c|c|}
\hline Adsorbents & $\begin{array}{l}\text { Level } \\
(\mathrm{g} / \mathrm{kg})\end{array}$ & $\begin{array}{l}\text { Mycotoxins } \\
(\mathrm{mg} / \mathrm{kg})\end{array}$ & $\begin{array}{l}\text { Duration } \\
\text { (days) }\end{array}$ & $\begin{array}{l}\text { Main effect of the inclusion of a mineral } \\
\text { adsorbent to the contaminated feed }\end{array}$ & References \\
\hline Bentonite & 10 & $\begin{array}{l}\mathrm{AFB}_{1}(0.02) \\
\text { ZEN }(2) \\
\text { OTA }(0.1)\end{array}$ & 42 & $\begin{array}{l}\text { No significant difference was observed in the } \\
\text { overall performance of bentonite-treated } \\
\text { birds }\end{array}$ & Pappas et al. (2014) \\
\hline Montmorillonite & 5 & $\begin{array}{l}\mathrm{T}-2(4) \\
\mathrm{HT}-2(0.66)\end{array}$ & 42 & $\begin{array}{l}\text { Significantly improved growth, serum } \\
\text { biochemical parameters and reduced the } \\
\text { level of toxins in tissues. }\end{array}$ & Yang et al. (2014) \\
\hline Bentonite & 7 & $\mathrm{AFB}_{1}(0.02)$ & 21 & $\begin{array}{l}\text { No significant differences were seen in terms } \\
\text { of feed intake and biochemical parameters } \\
\text { measured }\end{array}$ & Dos Anjos et al. (2015) \\
\hline Diatomaceous earth & 7.5 & $\mathrm{AFB}_{1}(0.02)$ & 21 & $\begin{array}{l}\text { Significantly decreased feed intake, body } \\
\text { weight and serum concentration of glucose, } \\
\text { albumin and protein }\end{array}$ & Anjos et al. (2016) \\
\hline Calcium bentonite & 2 & $\begin{array}{l}\mathrm{AFB}_{1}(200,400 \\
\quad 600, \text { and } 1800)\end{array}$ & 21 & $\begin{array}{l}\text { Treatment reduced the accumulation of } \mathrm{AFB}_{1} \\
\text { residues in the liver }\end{array}$ & Fowler et al. (2015) \\
\hline Bentonite & $3.7,7.5$ & $\begin{array}{l}\operatorname{AFB}_{1}(0.1,0.2,0.6) \\
\mathrm{OTA}(0.15,0.3,1)\end{array}$ & 21 & $\begin{array}{l}\text { Both concentrations of bentonite ameliorated } \\
\text { toxic effects of } 0.1 \text { and } 0.2 \mathrm{mg} / \mathrm{kg} \mathrm{AFB} \mathrm{AF}_{1} \\
\text { but no significant effects on OTA-treated } \\
\text { birds }\end{array}$ & Bhatti et al. (2016) \\
\hline HSCAS & 5 & $\begin{array}{l}\mathrm{AFB}_{1}(2) \\
\mathrm{FB}_{1}(10)\end{array}$ & 37 & $\begin{array}{l}\text { HSCAS did not have any significant effect on } \\
\text { reduced body weight and feed intake } \\
\text { induced by mycotoxins }\end{array}$ & Sobrane Filho et al. (2016) \\
\hline Bentonite & 10 & $\begin{array}{l}\operatorname{AFB}_{1}(0.1) \\
\mathrm{OTA}(0.1)\end{array}$ & 42 & $\begin{array}{l}\text { Significantly reduced OTA concentration in } \\
\text { liver and breast muscle by } 4 \text {-fold and } \\
\text { completely removed } \mathrm{AFB}_{1} \text { residues. }\end{array}$ & Pappas et al. (2016) \\
\hline Bentonite & 5 & $\mathrm{AFB}_{1}(2)$ & 21 & $\begin{array}{l}\text { Improved growth performance and increased } \\
\text { liver and kidney weight. }\end{array}$ & Shannon et al. (2017) \\
\hline Bentonite & 5 & $\begin{array}{l}\operatorname{AFB}_{1}(0.1,0.2,0.6) \\
\quad \text { OTA }(0.15,0.3,1)\end{array}$ & 42 & $\begin{array}{l}\text { Decreased } 41 \% \text { of } \mathrm{AFB}_{1} \text { residues in the liver } \\
\text { of broiler chicken }\end{array}$ & Bhatti et al. (2017) \\
\hline HSCAS & 3 & $\mathrm{AFB}_{1}(0.04)$ & 21 & $\begin{array}{l}\text { Significantly improved growth performance, } \\
\text { digestibility and reduced } \mathrm{AFB}_{1} \text { in liver and } \\
\text { kidney. }\end{array}$ & Liu et al. (2018) \\
\hline Bentonite & $5,10,20$ & OTA $(0.15,0.3,1)$ & 42 & $\begin{array}{l}\text { No significant effect on total antibody, } \\
\text { immunoglobulin titres and } \\
\text { lymphoproliferative responses. }\end{array}$ & Khatoon et al. (2018) \\
\hline Aluminosilicate & 1 & $\operatorname{AFB}_{1}(2,4)$ & 21 & $\begin{array}{l}\text { Increased body weight and feed efficiency as } \\
\text { well as haematological parameters and } \\
\text { serum proteins. }\end{array}$ & $\begin{array}{l}\text { Nazarizadeh and } \\
\text { Pourreza (2019) }\end{array}$ \\
\hline Modified HSCAS & 5 & $\mathrm{~T}-2(6)$ & 14 & $\begin{array}{l}\text { Prevented T- } 2 \text { toxin-induced decreased body } \\
\text { weight, feed intake, protein and total calci- } \\
\text { um and phosphorus }\end{array}$ & Wei et al. (2019) \\
\hline
\end{tabular}

countries: Mexico, Germany, Armenia, Turkey, Italy, Uzbekistan, Azerbaijan, Kazakhstan, Ukraine, Turkmenistan, Bulgaria, USA, Czech Republic, South Africa, Moldova, Greece, Indonesia, Japan, Australia, Kyrgyzstan, Russia, Belarus, Tajikistan (EHC 2005).

\section{Potential adverse effects of mineral adsorbents}

Mineral adsorbents are added to animal feed as a non-nutritive additive, to prevent lump formation (anti-caking agent and coagulant), improve farm animal performance and bind or reduce mycotoxins (Kolosova and Stroka 2012). The mechanism of action for sequestering mycotoxins remains controversial, and six mechanisms have been proposed: selective chemisorption, electron donating, hydrogen bonding, furan ring bonding, ion interactions and coordination between exchange cations and the carbonyl groups. However, most researchers believe the process is physical adsorption by ion exchange reaction and electrostatic interaction (Thimm et al. 2001; Deng et al. 2010; Wang et al. 2018). Similar mechanisms have also been proposed for the adsorption of nutritional content in animal diets including proteins (Ralla et al. 2010; Alam and Deng 2017), micronutrients (Schmidhalter et al. 1994; Barrientos-Velázquez et al. 2016), as well as veterinary drugs (Devreese et al. 2013). Furthermore, rate of adsorption is dependent on the origin and physicochemical properties of adsorbents and takes place predominantly in the acidic $\mathrm{pH}$ range (Deng et al. 2010).

Currently, bentonite, kaolinite, clinoptilolite, palygorskite, and montmorillonite are commercially available in natural and 
Table 2 Summary of physicochemical properties of mineral adsorbents commonly used for adsorbing mycotoxins (Deepthy and Balakrishnan 2005; Lantenois et al. 2008; Pushcharovsky et al. 2016)

\begin{tabular}{|c|c|c|c|c|}
\hline Adsorbent & Structure & $\mathrm{CEC}(\mathrm{cmol} / \mathrm{kg})$ & Surface area $\left(\mathrm{m}^{2} / \mathrm{g}\right)$ & Mode of formation \\
\hline Bentonite & 2:1 Lattice & $53-83$ & $370-490$ & $\begin{array}{l}\text { Alteration of volcanic ash in marine environment or silica bearing } \\
\text { rocks such as granite and basalt. }\end{array}$ \\
\hline Kaolinite & 1:1 Lattice & $3-15$ & $5-20$ & $\begin{array}{l}\text { Rock weathering or by hydrothermal process at high temperature or } \\
\text { at low temperature by the alteration of primary minerals (such as } \\
\text { feldspar). }\end{array}$ \\
\hline Montmorillonite & 2:1 Lattice & $80-100$ & $70-800$ & $\begin{array}{l}\text { Weathering products in soils at moderately high temperature } \\
\left(200^{\circ} \mathrm{C}\right)\end{array}$ \\
\hline Palygorskite & 2:1 Lattice & $4-40$ & $300-600$ & $\begin{array}{l}\text { Alteration of precursor minerals or by precipitation from rock } \\
\text { solution. }\end{array}$ \\
\hline Activated carbon & Pore & - & $300-4000$ & $\begin{array}{l}\text { Pyrolysis of different kinds of organic materials such as lignin, } \\
\text { coconut shell, peat, hard and soft wood, lignite coal and } \\
\text { carbonaceous materials. }\end{array}$ \\
\hline Zeolite (Clinoptilolite) & 1:2 Lattice & $180-600$ & $500-700$ & $\begin{array}{l}\text { Rock interaction with aqueous solution or fluid in a wide variety of } \\
\text { geochemical environments. }\end{array}$ \\
\hline
\end{tabular}

modified forms. Modified adsorbents tend to have higher mycotoxin-sequestering capacity, due to alteration in charge and surface properties of natural adsorbents, using modifiers such as acids, alkalis, and organic cations-ACO, VTMS, HDTM, BAC, OBAC, and CMAB (Baglieri et al. 2013; Nones et al. 2016; Wang et al. 2018). Concerning the safety of these agents, published studies are either contradictory or lack some degree of accuracy in their assessments. Negative effects induced in farm animals due to interaction with veterinary substances and micronutrients in feed as well as in vitro and in vivo toxicity of natural and modified mineral adsorbents are discussed as follows.

\section{Micronutrients}

Micronutrients including iron, iodine, calcium, magnesium, selenium, zinc, and vitamins are essential minerals or elements required in minute quantities (less than $100 \mathrm{mg} / \mathrm{kg}$ per day) by animals for proper functioning of enzymes and hormones, to maintain growth and development (Smith et al. 2018). Clays are considered to be a source of minerals for animals due to the possession of an anionic framework with well-defined microstructures containing chemical elements mostly alkali metal ions and trace elements (Bhaskaran and Gupta 2006; Suzanne et al. 2017). Moreover, these minerals are exchangeable during ion-exchange process that is largely influenced by $\mathrm{pH}$ and temperature, leading to either bioavailability of minerals or deficiency in the gastrointestinal tract (ingesta) of animal fed feed supplemented with mineral adsorbents (Lukman et al. 2013). For instance, the hydrochloric acid in the stomach (low $\mathrm{pH}$ ) and bile salts in the intestine (high $\mathrm{pH}$ ) may change the physiochemical properties of mineral adsorbents thereby enhancing their ion-exchange capacity. This process may lead to the release of minerals from the surface of the adsorbents into the surrounding milieu, thus increasing the concentration of minerals (in addition to mineral content of feed) in the systemic circulation and subsequent accumulation in the body (Park et al. 2002; Mascolo et al. 2004; MambaI et al. 2010). Also, the ion-exchange process, particularly for adsorbents with a high CEC, may lead to adsorption of minerals and nutrients from feed, resulting in the deficiencies of micronutrients such as iron, potassium, and vitamins in farm animals (Ralla et al. 2010).

Several publications have reported symptoms of vitamin A deficiency in chickens given feed supplemented with $0.5-3 \%$ bentonite (Briggs and Spivey 1999; Laughland and Phillips 2000; Hashemipour et al. 2010). Moreover, Erwin et al. (1998) demonstrated through an in vitro study that sodium bentonite has a strong affinity for pure carotene and can as well bind non-carotenoid pigments in feed (Erwin et al. 1998). With regard to trace elements, adverse effects observed in farm animals have been attributed to the imbalance between dietary concentration of trace elements in feed and the amount of trace elements in the mineral adsorbents (Thilsing et al. 2007; Grosicki and Rachubik 2010; Yang et al. 2017).

Supplementation of feed with either 10 or $20 \mathrm{~g} / \mathrm{kg}$ of palygorskite significantly decreased lead and copper accumulation in breast and thigh muscles of broiler chickens (Cheng et al. 2016). Correspondingly, inclusion of $0.5-2 \%$ zeolite and bentonite to chicken diet decreased serum levels of zinc, copper, and manganese, while aluminium concentration was significantly increased (Chung et al. 1990; Ivan et al. 1992; Utlu et al. 2007; Schwaller et al. 2016; Toprak et al. 2016). European Food Safety Authority Panel on Additives and Products used in Animal Feed (EFSA FEEDAP Panel) warned of a potential binding of manganese when bentonite is used at a dosage higher than $0.5 \%$ in feeds (EFSA FEEDAP Panel 2011a). Hooda et al. (2004) and Seim et al. (2013) also demonstrated different mechanisms by which mineral 
adsorbents (bentonite and halloysite) can inhibit the absorption of dietary iron in vitro (Hooda et al. 2004; Seim et al. 2013).

As the levels at which minerals occur in clays varies and dependent on geographical origin, it is essential to know the appropriate amount of clay and trace elements to be included in feed, to ensure animal welfare and productivity is not impaired by dietary mineral imbalances. Furthermore, a quality control system that includes adequate milling, cleaning, drying, and sieving as well as analysis of elemental composition, purity, and microbiological examination of final product must be established.

\section{Veterinary substances}

Due to non-specific effects of mycotoxin binders, EFSA has recommended evaluation of oral veterinary drugs in feed supplemented with a mycotoxin binder, to prove its safety towards binding of medical substances (EFSA FEEDAP Panel 2011a, b). Interaction of mineral adsorbents with veterinary substances has been reported for antibiotics such as tilmicosin, tylosin, paromomycin, doxycycline, and coccidiostats such as monensin and salinomycin. Goossens et al. (2012) studied the effects of bentonite on the oral bioavailability of doxycycline in pigs fed trichothecene-contaminated feed. The authors observed an increased plasma concentration of doxycycline administered as a single bolus in animals fed $100 \mu \mathrm{g} / \mathrm{kg}$ of T-2 and $1 \mathrm{mg} / \mathrm{kg}$ DON-contaminated diet when compared to control group. They suggested a complex interaction leading to increased oral bioavailability of antibiotics may occur when animals are given mycotoxin-contaminated diet, mycotoxin binders, and antibiotics concurrently (Goossens et al. 2012). Efficacies of monensin and salinomycin to prevent coccidiosis in chickens were reduced in the presence of $0.5 \%$ sodium bentonite (Gray et al. 1998). Addition of bentonites to chicken diet has been shown to be incompatible with the use of robenidine and is expected to reduce the effectiveness of other coccidiostats at levels higher than $0.5 \%$ (EFSA FEEDAP Panel 2011a, b). A bacteriostatic feed additive, tylosin, was unable to prevent airsacculitis and other clinical symptoms caused by Mycoplasma gallisepticum in broiler chickens fed a diet supplemented with $2 \%$ bentonite (Shryock et al. 1994).

An in vitro model simulating intestinal barrier was designed by Devreese et al. (2013) using porcine small intestinal epithelial cell line-J2 (IPEC-J2), to study efficacy and drug interaction testing of mycotoxin binders. The model was used to examine the passage of tylosin through the intestine in the presence of $1 \%$ bentonite. Bentonite interacted with tylosin and decreased its passage through IPEC-J2 (Devreese et al. 2013). Also, an in vitro study on adsorption of doxycycline by six different adsorbents (four montmorillonite based-clay, sepiolite and leonardite-based binder) showed that less than $25 \%$ of the initial concentration of doxycycline was detected after $4 \mathrm{~h}$ of incubation at $37^{\circ} \mathrm{C}$, suggesting that $75 \%$ of doxycycline was adsorbed by mineral adsorbents (De Mil et al. 2015). Furthermore, the in vitro results were validated using two of the montmorillonites-based clays, to study the pharmacokinetics and oral bioavailability of doxycycline in vivo. Results showed that the two binders significantly lowered the area under the plasma concentration-time curve of doxycycline by less than $60 \%$ when compared with the control group. Similar in vivo result was reported by Osselaere et al. (2012); they observed a significant alteration in pharmacokinetic profiles and oral bioavailability of oxytetracycline and amoxicillin. Additionally, significant concentration of oxytetracycline was found in the kidneys of treated birds (Osselaere et al. 2012) compared to control group. Taken together, if a mycotoxin binder decreases or enhances the oral absorption of drugs, it may have a significant consequence on animal health, withdrawal time of the antibiotics and potentially public health in terms of exposure to antibiotic residues.

\section{In vitro toxicity}

The in vitro toxicity of mineral adsorbents has been widely studied. Due to the potential of mineral adsorbents to enter the body through different routes including inhalation, ingestion, and dermal penetration, cell lines such as keratinocytes, alveolar macrophages, erythrocytes, endothelial, hepatocytes, epithelial, and fibroblasts have been used to investigate toxic effects of mineral adsorbents (Elmore 2003; Maisanaba et al. 2015a). These cell lines represent major organs where adsorbent particles are localized and accumulated when humans and animals are exposed to clay particles via different routes Michel et al. 2014; Connolly et al. 2019; Boim et al. 2019). Several in vitro toxicity studies of clay minerals have suggested an interaction or crosstalk between the surface of clay particles and cellular receptors (Verma et al. 2012; Michel et al. 2014). Furthermore, techniques such as fluorescence microscopy, transmission electron microscopy, time-lapse video microscopy, and histocytological staining have been utilized to show uptake of clay particles by macrophages and lymphocytes (Bowman et al. 2011; Kuhn et al. 2014; Connolly et al. 2019) as well as internalization by cell types such as keratinocytes and hepatocytes, through endocytosis and micropinocytosis pathways (Michel et al. 2014; Kuhn et al. 2014; Castro-Smirnov et al. 2017; Connolly et al. 2019). Also, accessory minerals such as quarts and metal oxides including $\mathrm{TiO}_{2}$ and $\mathrm{ZnO}$ contained within clays have been suggested to be responsible for toxicity induced in different cell lines, with degree of toxicity dependent on size, shape, surface properties, and chemical composition of the adsorbent (Geh et al. 2006; Li et al. 2010).

To elucidate mechanism of toxicity, different biomarkers such as lactate dehydrogenase leakage, reactive oxygen species generation, superoxide dismutase inhibition, and 
malondialdehyde release have been assayed ( $\mathrm{Li}$ et al. 2010; Zhang et al. 2010; Baek et al. 2012; Lordan et al. 2010; Maisanaba et al. 2014). Furthermore, comet, Ames, and CBMN assays were used to detect DNA damage and chromosomal loss (Li et al. 2010; Maisanaba et al. 2015a). Mineral adsorbents used for the assays are generally prepared by making up a suspension and measuring the absorbance to determine the concentration, followed by a multi-step ultrasonication at $40 \%$ vibration amplitude to disperse the suspension. Finally, the known stock solution is serially diluted in cell culture medium and vortexed vigorously before being applied to cells. The culture medium without mineral adsorbent is used as the control. The majority of publications on the topic found mineral adsorbents to be toxic while a smaller number observed little or no effects.

An investigation of short and long term toxicity of montmorillonite in human normal intestinal cells (INT-407) by Baek et al. (2012) revealed that montmorillonite (20$1000 \mu \mathrm{g} / \mathrm{mL}$ ) can inhibit cell proliferation, induce oxidative stress and membrane damage between 24 and $72 \mathrm{~h}$, with more remarkable cytotoxicity after long-term exposure (10 days) (Baek et al. 2012). Apoptosis and oxidative stress were also observed in human B lymphoblast cells exposed to $120 \mu \mathrm{g} /$ $\mathrm{mL}$ and $240 \mu \mathrm{g} / \mathrm{mL}$ of natural bentonite and bentonite modified with $10-15 \%$ of $\mathrm{H}_{2} \mathrm{SO}_{4}$, within $24 \mathrm{~h}$ of exposure (Zhang et al. 2010). Furthermore, oxidative stress induced by modified bentonite was significantly higher than that of natural bentonite (Zhang et al. 2010). In terms of cell viability, CHO (ovary) and HepG2 (liver) cells exposed to montmorillonite $(100-1000 \mu \mathrm{g} / \mathrm{mL})$ exhibited a reduced viability and cytotoxic effects in a dose-dependent manner after $12-24 \mathrm{~h}$ of exposure (Li et al. 2010; Nones et al. 2015). Houtman et al. (2014) and Maisanaba et al. (2017) also observed reduced cell viability in Caco-2 (intestine) and HepG2 cell lines exposed to adsorbents modified with HDTM, ACO, and VTMS at 24 and $48 \mathrm{~h}$ of exposure (Houtman et al. 2014; Maisanaba et al. 2017). Other researchers (Verma et al. 2012; Maisanaba et al. 2015b) did not observe any reduction in viability of Caco-2, human umbilical vein endothelial (HUVEC), and A549 (human alveolar epithelial) cells exposed to mineral adsorbents. This may be due to the concentrations tested and type of adsorbents used. For instance, Maisanaba et al. (2015b) used a very low concentration range $(0-8 \mu \mathrm{g} / \mathrm{mL})$ of montmorillonite and both Verma et al. (2012) and Liu et al. (2012) used halloysite clays (aluminosilicates) (Verma et al. 2012; Maisanaba et al. 2015b).

Regarding the genotoxicity of mineral adsorbents, EFSA FEEDAP Panel found algae interspaced bentonite to be nongenotoxic or mutagenic at the highest concentration tested, $250 \mu \mathrm{g} / \mathrm{mL}$ (EFSA FEEDAP Panel 2016). In a recently published opinion (EFSA FEEDAP Panel 2017), it was also reiterated that bentonite is non-genotoxic. Likewise, Geh et al. (2006), Li et al. (2010), and Maisanaba et al. (2014) did not observe any genotoxic effects when cells were exposed to natural or unmodified mineral adsorbents. Nevertheless, contrary results were observed in the case of modified adsorbents. Exposure of HepG2 cells to $15.6 \mu \mathrm{g} / \mathrm{mL}$ organo-modified montmorillonite significantly increased the frequency of micronuclei by 2.7 -fold compared to control group using both comet and CBMN assays. Additionally, genes involved in DNA damage, metabolism, and oxidative stress were upregulated (Maisanaba et al. 2016). Similarly, HepG2 and Caco-2 cells exposed to $88 \mu \mathrm{g} / \mathrm{mL}$ and $141 \mu \mathrm{g} / \mathrm{mL}$ respectively of modified montmorillonite showed a significant increase in DNA damage after $48 \mathrm{~h}$ of exposure (Sharma et al. 2010; Maisanaba et al. 2013).

In vitro toxicity testing plays an important role in the analysis of toxic effects of chemical substances and helps to identify potentially hazardous chemicals in the environment in a rapid and cost-effective way (Maisanaba et al. 2015b). In vitro toxicological studies of mineral adsorbents suggest adsorbents, especially modified ones, may induce dose-dependent deleterious effects on various cell lines. With respect to the dosage used in the studies, there were challenges in describing the in vitro kinetics in the culture medium and actual kinetics when cells in the target tissue are exposed to the chemical substances. As in vitro models do not accurately determine the consequences of in vivo exposure because of differences in cell phenotype, immune systems, diverse protein reactions, intracellular signaling and fluidic environment (Baek et al. 2012), it is imperative to also evaluate toxicity of mineral adsorbents in animal models, taking into consideration their various applications in livestock nutrition.

\section{In vivo toxicity}

As stated earlier, several studies have shown that mineral adsorbents can alleviate negative effects induced by mycotoxins in farm animals (Table 1), other studies however, have reported undesirable effects in animal groups fed diets (with or without mycotoxins) supplemented with mineral adsorbents. Khatoon et al. (2018) observed a significant reduction in the total immunoglobulin, lymphoproliferative response and total antibody in birds fed OTA-contaminated diet $(0.15-1.0 \mathrm{mg}$ $\mathrm{OTA} / \mathrm{kg}$ ) and $0.5-2 \%$ of bentonite clay (Khatoon et al. 2018). Significant decrease in creatinine, uric acid, and cholesterol serum levels were also seen in broiler chickens fed $\mathrm{AFB}_{1}$ plus $0.25 \%$ and $0.5 \%$ clinoptilolite (Maciel et al. 2007). Three milligrams per kilogram of $\mathrm{AFB}_{1}$ plus sodic montmorillonite $(0.25$ and $0.5 \%)$ significantly protected against the toxic effects of $\mathrm{AFB}_{1}$ in pigs; however, $0.5 \%$ of sodic montmorillonite significantly reduced the level of serum phosphorus (Franciscato et al. 2006).

In layer birds, inclusion of $2 \%$ clinoptilolite to diet contaminated with $2.5 \mathrm{mg} \mathrm{AFB} / \mathrm{kg}$ significantly decreased egg weight and egg yolk index (Rizzi et al. 2003). Significant 
decrease in triiodothyronine and thyroxine hormones were also observed in birds fed 2.5-5\% of bentonite and $1 \mathrm{mg} / \mathrm{kg}$ of $\mathrm{AFB}_{1}$ (Eraslan et al. 2005). Addition of $4 \mathrm{~g} / \mathrm{kg}$ of aluminosilicates to female weaned piglets diet contaminated with $8.6 \mathrm{mg} \mathrm{DON} / \mathrm{kg}$ and $1.2 \mathrm{mg} \mathrm{ZEN} / \mathrm{kg}$ significantly decreased feed intake and serum concentration of cholesterol. Furthermore, treated animals exhibited significant increase in the activities of aspartate transaminase and $\gamma$ glutamyltransferase as well as serum concentration of albumin (Döll et al. 2005). The efficacy of low-pH montmorillonites modified with HDTMA and HDA to sequester ZEN was investigated in vivo using uterine weight of mice (Lemke et al. 2001). Supplementation of $0.5 \%$ modified montmorillonites with ZEN-contaminated feed did not only reduce the body weight of animals but also enhanced the toxicity of ZEN (increase in uterine weight). The authors concluded that alkylamine groups may promote the uptake of ZEN from a contaminated diet and result in an enhanced toxicity (Lemke et al. 2001). In all the studies outlined, negative effects of adsorbents were observed not only in animal groups fed mycotoxin-contaminated diet with mineral adsorbents but also in group fed mycotoxin-free diet plus mineral adsorbents.

Many of the studies that reported protective actions of mineral adsorbents against toxic effects of mycotoxins in vivo focused mainly on zootechnical parameters such as feed intake and body weight gain without investigating the potential negative (unwanted) effects of mineral binders, as previously discussed by Döll and Dänicke (2004) (Döll and Dänicke 2004). The studies generally used three experimental groups: a negative control group (mycotoxin-free diet), positive control group (mycotoxin-contaminated diet), and treated group (mycotoxin-contaminated diet and mineral adsorbent), to demonstrate the efficacy of the mineral binders. However, a group of animals were not included (mycotoxin-free diet with mineral adsorbent) to investigate nonspecific effects of mineral binders, which may occur independently of mycotoxin contamination. Therefore, the safety or efficacy of such mineral binders has not been proven in a satisfactory manner. Other studies that investigated the effects of dietary mineral adsorbents (not as mycotoxin binder) have observed various negative effects.

Pigs fed a diet supplemented with $2.5 \%$ and $5 \%$ montmorillonite experienced hepatic histological changes including swelling, vacuolar and vesicular degeneration. Furthermore, antioxidant capacity, glutathione peroxidase and average daily feed intake were severely affected compared to control group (Zhao et al. 2017). The authors concluded that inclusion of montmorillonite to a diet at a concentration above $1 \%$ may not be safe for starter pigs. Prvulović et al. (2008) also investigated the effects of dietary supplementation of $0.5 \%$ clinoptilolite on performance and biochemical parameters of pigs. They found a significant increase in body weight gain of pigs in the first 90 days; however, after 120 days, there was a significant decrease in growth rate as well as increased activity of aspartate aminotransferase in serum of clinoptilolite-treated group (Prvulović et al. 2008). In commercial layers, Berto et al. (2013) found that $0.5 \%$ inclusion of clinoptilolite to feed led to a decrease in animal performance and eggshell quality (Berto et al. 2013). Similarly, the addition of 1-3\% of sodium bentonite decreased specific gravity, yolk color index, feed consumption, and egg production compared to birds fed control diet (Roland 1988; Hashemipour et al. 2010).

The global occurrence of mycotoxins in feed ingredients is of great concern as it is considered to be a major risk factor for animal performance and human health. One of the strategies for mitigating the occurrence of mycotoxins in feed is the inclusion of mineral adsorbents to feed. Several authors have proven these substances to be effective in alleviating mycotoxicosis in farm animals fed contaminated feeds. The FEEDAP Panel have also assessed the efficacy and safety of natural bentonite, they concluded that bentonite with following composition: $\geq 70 \%$ smectite (dioctahedral montmorillonite), $<10 \%$ opal and feldspar, and $<4 \%$ quartz and calcite is effective for binding $\mathrm{AFB}_{1}$ and safe for all animal species when used at a maximum level of $20,000 \mathrm{mg} / \mathrm{kg}$ in complete compound feed. Several of these products have been approved by EFSA and are available on the European market as either feed additives or digestibility enhancers. However, in other countries, there is no regulation on the use of these products, and they are listed as raw material catalogue such as bentonite, kaolinite, HSCAS, and palygorskite. Moreover, very limited information is available on their composition or physicochemical properties. Therefore, utilization of such adsorbents as feed additives must be carefully considered by farmers and animal nutrition companies.

With regard to modified mineral adsorbents, very few researchers have investigated the safety of these products and both their efficacy and safety have not been assessed by the FEEDAP Panel. As it is essential to verify the potential of a mineral adsorbent to adsorb mycotoxins in vitro and in vivo, their safety and potential interaction with nutrients and veterinary substances in feeds must also be considered, using a complete experimental design: non-contaminated diet (negative control); mycotoxin-contaminated diet (positive control); non-contaminated diet with the mycotoxin binder and mycotoxin-contaminated diet with mycotoxin binder.

In summary, available data have shown that both natural and modified adsorbents or mycotoxin binders can induce cytotoxic effects including oxidative stress, reduction in cell viability, apoptosis, and DNA damage. They can bind essential micronutrients and vitamins in feed leading to reduced feed conversion, immunosuppression, and low productivity in livestock animals. Moreover, they can interact with veterinary drugs, which may cause a decline or an increase in the oral absorption of drugs, leading to a potential therapy failure and higher levels of antibiotic residues in foods of animal origin. Mineral adsorbents may also contain variable amounts of 
accessory minerals (quarts, nontronite, erionite), heavy metals (lead, copper, cadmium), dioxins, and trace elements, which can induce toxicity in livestock animals as well as alter serum mineral profile and activities of enzymes such as glutamate dehydrogenase, aminotransferase, creatinine, and glutathione peroxidase.

Funding information This work has received funding from the European Union's Horizon 2020 research and innovation program under the Marie Skłodowska-Curie grant agreement no. 722634.

\section{Compliance with ethical standards}

Conflict of interest The authors declare that they have no conflict of interest.

Open Access This article is distributed under the terms of the Creative Commons Attribution 4.0 International License (http:// creativecommons.org/licenses/by/4.0/), which permits unrestricted use, distribution, and reproduction in any medium, provided you give appropriate credit to the original author(s) and the source, provide a link to the Creative Commons license, and indicate if changes were made.

\section{References}

Alam S, Deng Y (2017) Protein interference on aflatoxin B1 adsorption by smectites in corn fermentation solution. Appl Clay Sci 144:3644. https://doi.org/10.1016/j.clay.2017.04.024

Alaniz C, Regil E, Cruz G, Torres J, Monroy J (2012) Composition and properties of tectosilicate-uranium layers of soil. Eur J Chem 3:3236. https://doi.org/10.5155/eurjchem.3.1.32-36.525

Alltech 8th Annual Global Feed Survey (2019). Available at: https://go. alltech.com/alltech-feed-survey. Accessed 24th March 2019

Andrade F, Al-Qureshi H, Hotza D (2011) Measuring the plasticity of clays: a review. Appl Clay Sci 51:1-7. https://doi.org/10.1016/j.clay. 2010.10 .028

Anjos F, Ledoux D, Rottinghaus G, Chimonyo M (2016) Efficacy of Mozambican bentonite and diatomaceous earth in reducing the toxic effects of aflatoxins in chicks. World Mycotoxin J 9:63-72. https:// doi.org/10.3920/WMJ2014.1842

Avantaggiato G, Solfrizzo M, Visconti A (2005) Recent advances on the use of adsorbent materials for detoxification of Fusarium mycotoxins. Food Addit Contam 22:379-388. https://doi.org/10.1080/ 02652030500058312

Baek M, Lee J, Choi S (2012) Toxicological effects of a cationic clay, montmorillonite in vitro and in vivo. MCT 8:95-101. https://doi. org/10.1007/s13273-012-0012-x

Baglieri A, Reyneri A, Gennari M, Nègre M (2013) Organically modified clays as binders of fumonisins in feedstocks. J Environ Sci Health B 48:776-783. https://doi.org/10.1080/03601234.2013.780941

Barrientos-Velázquez AL, Arteaga S, Dixon JB, Deng Y (2016) The effects of $\mathrm{pH}$, pepsin, exchange cation, and vitamins on aflatoxin adsorption on smectite in simulated gastric fluids. Appl Clay Sci 120:17-23. https://doi.org/10.1016/j.clay.2015.11.014

Berto D, Garcia E, Pelícia K, Vercese F, Molino A, Silveira A, Vieira Filho J, Murakami O (2013) Effects of dietary clinoptilolite and calcium levels on the performance and egg quality of commercial layers. Rev. Bras. Ciênc. Avíc. 15:263-268. https://doi.org/10. 1590/S1516-635X2013000300014
Bhaskaran S, Gupta G (2006) Adsorption of trace elements from poultry litter by montmorillonite clay. J Hazard Mater 128:80-83. https:// doi.org/10.1016/j.jhazmat.2005.05.036

Bhatti SA, Khan MZ, Saleemi MK, Saqib M (2016). Aflatoxicosis and ochratoxicosis in broiler chicks and their amelioration with locally available bentonite clay. Pak. Vet. J 36:68-72

Bhatti S, Khan M, Hassan Z, Saleemi M, Saqib M, Khatoon A, Akhter M (2017) Comparative efficacy of bentonite clay, activated charcoal and Trichosporon mycotoxinivorans in regulating the feed-to-tissue transfer of mycotoxins. J Sci Food Agric 98:884-890. https://doi. org/10.1002/jsfa.8533

Boim A, Wragg J, Canniatti-Brazaca S, Alleoni L (2019) Human intestinal Caco-2 cell line in vitro assay to evaluate the absorption of $\mathrm{Cd}$, $\mathrm{Cu}, \mathrm{Mn}$ and $\mathrm{Zn}$ from urban environmental matrices. Environ Geochem Health. https://doi.org/10.1007/s10653-019-00394-4

Bowman P, Wang X, Meledeo M, Dubick M, Kheirabadi B (2011) Toxicity of aluminum silicates used in hemostatic dressings toward human umbilical veins endothelial cells, HeLa cells, and RAW267.4 mouse macrophages. J Trauma 71:727-732. https://doi.org/10. 1097/ta.0b013e3182033579

Briggs G, Spivey F (1999) Vitamin A deficiency in chicks produced by adding high levels of bentonite to synthetic diets. Poult Sci 35:570 576. https://doi.org/10.3382/ps.0350570

Castro-Smirnov F, Ayache J, Bertrand J, Dardillac E, Le Cam E, Piétrement, O (2017) Cellular uptake pathways of sepiolite nanofibers and DNA transfection improvement. Sci Rep 7. https://doi.org/ 10.1038/s41598-017-05839-3

Cheng Y, Chen Y, Li X, Yang W, Wen C, Zhou Y (2016) Effects of palygorskite inclusion on the growth performance, meat quality, antioxidant ability, and mineral element content of broilers. Biol Trace Elem Res 173:194-201. https://doi.org/10.1007/s12011-0160649-8

Chung T, Ekdman J, Baker D (1990) Hydrated sodium calcium aluminosilicate: effects on zinc, manganese, vitamin a, and riboflavin utilization. Poult Sci 69:1364-1370. https://doi.org/10.3382/ps.0691364

Connolly M, Zhang Y, Mahri S, Brown D, Ortuño N, Jordá-Beneyto M (2019) The influence of organic modification on the cytotoxicity of clay particles to keratinocytes, hepatocytes and macrophages; an investigation towards the safe use of polymer-clay nanocomposite packaging. Food Chem Toxicol 126:178-191. https://doi.org/10. 1016/j.fct.2019.02.015

De Mil T, Devreese M, Broekaert N, Fraeyman S, De Backer P, Croubels $\mathrm{S}$ (2015) In vitro adsorption and in vivo pharmacokinetic interaction between doxycycline and frequently used mycotoxin binders in broiler chickens. J Agric Food Chem 63:4370-4375. https://doi. org/10.1021/acs.jafc.5b00832

Deepthy R, Balakrishnan S (2005) Climatic control on clay mineral formation: evidence from weathering profiles developed on either side of the western Ghats. J Earth Syst Sci 114:545-556. https://doi.org/ 10.1007/BF02702030

Dellafiora L, Dall'Asta C (2017) Forthcoming challenges in mycotoxins toxicology research for safer food - a need for multi-omics approach. Toxins 9:18. https://doi.org/10.3390/toxins9010018

Deng Y, Velázquez A, Billes F, Dixon J (2010) Bonding mechanisms between aflatoxin B1 and smectite. Appl Clay Sci 50:92-98. https://doi.org/10.1016/j.clay.2010.07.008

Devreese M, Pasmans F, De Backer P, Croubels S (2013) An in vitro model using the IPEC-J2 cell line for efficacy and drug interaction testing of mycotoxin detoxifying agents. Toxicol in Vitro 27:157163. https://doi.org/10.1016/j.tiv.2012.09.020

Di Gregorio M, Neeff D, Jager A, Corassin C, Carão Á, Albuquerque R, Azevedo A, Oliveira C (2014) Mineral adsorbents for prevention of mycotoxins in animal feeds. Toxin Rev 33:125-135. https://doi.org/ $10.3109 / 15569543.2014 .905604$ 
Döll S, Dänicke S (2004) In vivo detoxification of Fusarium toxins. Arch Anim Nutr 58:419-441. https://doi.org/10.1080/ 00039420400020066

Döll S, Gericke S, Danicke S, Raila J, Ueberschar K, Valenta H, Schnurrbusch U, Schweigert F, Flachowsky G (2005) The efficacy of a modified aluminosilicate as a detoxifying agent in Fusarium toxin contaminated maize containing diets for piglets. J Anim Physiol Anim Nutr 89:342-358. https://doi.org/10.1111/j.14390396.2005.00527.x

Dos Anjos F, Ledoux D, Rottinghaus G, Chimonyo M (2015) Efficacy of adsorbents (bentonite and diatomaceous earth) and turmeric (Curcuma longa) in alleviating the toxic effects of aflatoxin in chicks. Br Poult Sci 56:459-469. https://doi.org/10.1080/ 00071668.2015.1053431

Dwyer M, Kubena L, Harvey R, Mayura K, Sarr A, Buckley S (1997) Effects of inorganic adsorbents and cyclopiazonic acid in broiler chickens. Poult Sci 76:1141-1149. https://doi.org/10.1093/ps/76.8. 1141

European Commission regulation (EC) No. 386/2009 of 12 May 2009 amending Regulation (EC) No. 1831/2003 of the European Parliament and of the Council as regards the establishment of a new functional group of feed additives Off. J. EU. L, 118 (2009), p. 66. https://doi.org/10.2903/sp.efsa.2009.EN-22

Panel on additives and products or substances used in animal feed (EFSA FEEDAP Panel) (2011a) Scientific opinion on the safety and efficacy of bentonite (dioctahedral montmorillonite) as feed additive for all species. EFSA J 9:2007. https://doi.org/10.2903/j. efsa.2011.2007

Panel on additives and products or substances used in animal feed (EFSA FEEDAP Panel) (2011b) Scientific opinion on the efficacy of bentonite (dioctahedral montmorillonite) for all species. EFSA J 9:2276. https://doi.org/10.2903/j.efsa.2011.2276

Panel on additives and products or substances used in animal feed (EFSA FEEDAP Panel) (2012) Scientific opinion on the safety and efficacy of bentonite as a technological feed additive for all species. EFSA J 10:2787. https://doi.org/10.2903/j.efsa.2012.2787

Panel on additives and products or substances used in animal feed (EFSA FEEDAP Panel) (2016) Safety and efficacy of a preparation of algae interspaced bentonite as a feed additive for all animal species. EFSA J 14:4623. https://doi.org/10.2903/j.efsa.2016.4623

Panel on additives and products or substances used in animal feed (EFSA FEEDAP Panel) (2017) Scientific opinion safety and efficacy of bentonite as a feed additive for all animal species. EFSA J 15: 5096. https://doi.org/10.2903/j.efsa.2017.5096

Environmental Health Criteria (EHC) Monographs (2005) Bentonite, kaolin, and selected clay minerals. Available at: http://www.who.int/ iris/handle/10665/43102. Accessed 25 June 2018

Elmore J (2003) Final report on the safety assessment of aluminium silicate, calcium silicate, magnesium aluminium silicate, magnesium silicate, magnesium trisilicate, sodium magnesium silicate, zirconium silicate, attapulgite, bentonite, fuller's earth, hectorite, kaolin, lithium magnesium silicate, lithium magnesium sodium silicate, montmorillonite, pyrophyllite, and zeolite. Int J Toxicol 22:37-102

Eraslan G, Essiz D, Akdogan M, Sahindokuyucu F, Altintas L, Hismiogullari SE (2005) Effects of dietary aflatoxin and sodium bentonite on some hormones in broiler chickens. Bull Vet Inst Pulawy 49:93-96

Erwin E, Elam C, Dyer I (1998) The influence of sodium bentonite in vitro and in the ration of steers. J Anim Sci 16:858-862. https://doi.org/ $10.2527 /$ jas $1957.164858 \mathrm{x}$

Fowler J, Li W, Bailey C (2015) Effects of a calcium bentonite clay in diets containing aflatoxin when measuring liver residues of aflatoxin B1 in starter broiler chicks. Toxins 7:3455-3464. https://doi.org/10. 3390/toxins 7093455

Franciscato C, Lopes ST, Santurio J, Wolkmer P, Maciel RM, De Paula MT, Garmatz BC, Costa MM (2006) Seric mineral concentrations and hepatic and renal functions of chickens intoxicated by aflatoxin and treated with sodic montmorillonite. Pesq Agrop Brasileira 41: 1573-1577. https://doi.org/10.1590/S0100-204X2006001100001

Geh S, Shi T, Shokouhi B, Schins R, Armbruster L, Rettenmeier A, Dopp E (2006) Genotoxic potential of respirable bentonite particles with different quartz contents and chemical modifications in human lung fibroblasts. Inhal Toxicol 18:405-412. https://doi.org/10.1080/ 08958370600563524

Ghadiri M, Chrzanowski W, Rohanizadeh R (2015) Biomedical applications of cationic clay minerals. RSC Adv 5:29467-29481. https:// doi.org/10.1039/C4RA16945J

Gilbert M, Medina A, Mack B, Lebar M, Rodríguez A, Bhatnagar D, Magan N, Obrian G, Payne G (2017) Carbon dioxide mediates the response to temperature and water activity levels in aspergillus flavus during infection of maize kernels. Toxins 10:5. https://doi. org/10.3390/toxins 10010005

Goossens J, Vandenbroucke V, Pasmans F, De Baere S, Devreese M, Osselaere A, Verbrugghe E, Haesebrouck F, De Saeger S, Eeckhout M, Audenaert K, Haesaert G, De Backer P, Croubels S (2012) Influence of mycotoxins and a mycotoxin adsorbing agent on the oral bioavailability of commonly used antibiotics in pigs. Toxins 4:281-295. https://doi.org/10.3390/toxins4040281

Gray S, Ward T, Southern L, Ingram D (1998) Interactive effects of sodium bentonite and coccidiosis with monensin or salinomycin in chicks. Poult Sci 77:600-604. https://doi.org/10.1093/ps/77.4.600

Grosicki A, Rachubik J (2010) Effect of bentonite on supplemental zinc uptake and distribution in rats. Bull Vet Inst Pulawy 54:665-668

Guerre P (2016) Worldwide mycotoxins exposure in pig and poultry feed formulations. Toxins 8:350. https://doi.org/10.3390/toxins8120350

Hashemipour H, Kermanshah H, Pilevar M (2010) Interactive effect of sodium bentonite with pigments on performance and egg quality of laying hens. J Anim Vet Adv 9:2179-2184. https://doi.org/10.3923/ javaa.2010.2179.2184

Hooda P, Henry C, Seyoum T, Armstrong L, Fowler M (2004) The potential impact of soil ingestion on human mineral nutrition. Sci Total Environ 333:75-87. https://doi.org/10.1016/j.scitotenv.2004. 04.023

Houtman J, Maisanaba S, Puerto M, Gutiérrez-Praena D, Jordá M, Aucejo S, Jos A (2014) Toxicity assessment of organomodified clays used in food contact materials on human target cell lines. Appl Clay Sci 90:150-158. https://doi.org/10.1016/j.clay.2014.01. 009

Huwig A, Freimund S, Käppeli O, Dutler H (2001) Mycotoxin detoxication of animal feed by different adsorbents. Toxicol Lett 122:179188. https://doi.org/10.1016/S0378-4274(01)00360-5

International Feed Industry Federation (IFIF) (2018). Available at: http:// www.ifif.org/pages/t/Global+feed+production. Accessed 24 Oct 2018

Ito A, Wagai R (2017) Global distribution of clay-size minerals on land surface for biogeochemical and climatological studies. Sci Data 4: 170103. https://doi.org/10.1594/PANGAEA.868929

Ittiphalin M, Nakrachata-Amon T, Pathumnakul S (2015) Feed formulation under raw material and production costs consideration. Appl Mech Mater 781:667-670. https://doi.org/10.4028/www.scientific. net/AMM.781.667

Ivan M, Dayrell M, Hidiroglou M (1992) Effects of bentonite and monensin on selected elements in the stomach and liver of faunafree and faunated sheep. J Dairy Sci 75:201-208. https://doi.org/10. 3168/jds.S0022-0302(92)77754-6

Khatoon A (2016) Toxicopathological and serum biochemical alterations induced by ochratoxin a in broiler chicks and their amelioration by locally available bentonite clay. Pak J Agric Sci 53:977-984. https:// doi.org/10.21162/PAKJAS/16.5573

Khatoon A, Khan MZ, Abidin ZU, Bhatti SA (2018) Effects of feeding bentonite clay upon ochratoxin a - induced immunosuppression in 
broiler chicks. Food Addit Contam Part A 35:538-545. https://doi. org/10.1080/19440049.2017.1411612

Kolosova A, Stroka J (2011) Substances for reduction of the contamination of feed by mycotoxins: a review. World Mycotoxin J 4:225256. https://doi.org/10.3920/WMJ2011.1288

Kolosova A, Stroka J (2012) Evaluation of the effect of mycotoxin binders in animal feed on the analytical performance of standardised methods for the determination of mycotoxins in feed. Food Addit Contam Part A 29:1959-1971. https://doi.org/10.1080/19440049. 2012.720035

Kosicki R, Błajet-Kosicka A, Grajewski J, Twarużek M (2016) Multiannual mycotoxin survey in feed materials and feeding stuffs. Anim Feed Sci Technol 215:165-180. https://doi.org/10.1016/j. anifeedsci.2016.03.012

Kuhn D, Vanhecke D, Michen B, Blank F, Gehr P, Petri-Fink A, RothenRutishauser B (2014) Different endocytotic uptake mechanisms for nanoparticles in epithelial cells and macrophages. J Nanotechnol 5: 1625-1636. https://doi.org/10.3762/bjnano.5.174

Lantenois S, Champallier R, Bény J, Muller F (2008) Hydrothermal synthesis and characterization of dioctahedral smectites: a montmorillonites series. Appl Clay Sci 38:165-178. https://doi.org/10.1016/j. clay.2007.03.005

Laughland D, Phillips W (2000) The effect of dietary sodium bentonite on the rate of growth of chicks. Poult Sci 35:1050-1054. https://doi. org/10.3382/ps.0351050

Lemke S, Mayura K, Reeves W, Wang N, Fickey C, Phillips T (2001) Investigation of organophilic montmorillonite clay inclusion in zearalenone-contaminated diets using the mouse uterine weight bioassay. J Toxic Environ Health A 62(4):243-258. https://doi.org/10. 1080/009841001459405

Li P, Wei J, Chiu Y, Su H, Peng F, Lin J (2010) Evaluation on cytotoxicity and genotoxicity of the exfoliated silicate nanoclay. ACS Appl Mater Interfaces 2:1608-1613. https://doi.org/10.1021/am1001162

Li X, Zhao L, Fan Y, Jia Y, Sun L, Ma S, Ji C, Ma Q, Zhang J (2014) Occurrence of mycotoxins in feed ingredients and complete feeds obtained from the Beijing region of China. J Anim Sci Biotechno 5: 37. https://doi.org/10.1186/2049-1891-5-37

Liu M, Zhang Y, Wu C, Xiong S, Zhou C (2012) Chitosan/halloysite nanotubes bionanocomposites: structure, mechanical properties and biocompatibility. Int J Biol Macromol 51:566-575. https://doi. org/10.1016/j.ijbiomac.2012.06.022

Liu N, Wang J, Deng Q, Gu K, Wang J (2018) Detoxification of aflatoxin B 1 by lactic acid bacteria and hydrated sodium calcium aluminosilicate in broiler chickens. Livest Sci 208:28-32. https://doi.org/10. 1016/j.livsci.2017.12.005

Lordan S, Kennedy J, Higginbotham C (2010) Cytotoxic effects induced by unmodified and organically modified nanoclays in the human hepatic HepG2 cell line. J Appl Toxicol 31:27-35. https://doi.org/ 10.1002/jat.1564

Lukman S, Essa M, Mu'azu N, Bukhari A, Basheer C (2013) Adsorption and desorption of heavy metals onto natural clay material: influence of initial pH. J Environ Sci Technol 6:1-15. https://doi.org/10.3923/ jest.2013.1.15

Maciel RM, Lopes ST, Santurio JM, Martins DB, Rosa AP, Emanuelli MP (2007) Hepatic and renal function of broilers fed diets with aflatoxins and natural clinoptilolite. Pesq Agrop Brasileira 42: 1221-1225. https://doi.org/10.1590/S0100-204X2007000900002

Maisanaba S, Puerto M, Pichardo S, Jordá M, Moreno F, Aucejo S, Jos Á (2013) In vitro toxicological assessment of clays for their use in food packaging applications. Food Chem Toxicol 57:266-275. https:// doi.org/10.1016/j.fct.2013.03.043

Maisanaba S, Gutiérrez-Praena D, Puerto M, Moyano R, Blanco A, Jordá M, Cameán A, Aucejo S, Jos Á (2014) Effects of the subchronic exposure to an organomodified clay mineral for food packaging applications on wistar rats. Appl Clay Sci 95:37-40. https://doi. org/10.1016/j.clay.2014.04.006
Maisanaba S, Gutiérrez-Praena D, Pichardo S, Moreno F, Jordá M, Cameán A, Aucejo S, Jos Á (2015a) Toxic effects of a modified montmorillonite clay on the human intestinal cell line Caco-2. J Appl Toxicol 34:714-725. https://doi.org/10.1002/jat.2945

Maisanaba S, Prieto A, Pichardo S, Jordá-Beneyto M, Aucejo S, Jos Á (2015b) Cytotoxicity and mutagenicity assessment of organomodified clays potentially used in food packaging. Toxicol in Vitro 29:1222-1230. https://doi.org/10.1016/j.tiv.2015.03.010

Maisanaba S, Hercog K, Filipic M, Jos Á, Zegura B (2016) Genotoxic potential of montmorillonite clay mineral and alteration in the expression of genes involved in toxicity mechanisms in the human hepatoma cell line HepG2. J Hazard Mater 304:425-433. https:// doi.org/10.1016/j.jhazmat.2015.10.018

Maisanaba S, Ortuño N, Jordá-Beneyto M, Aucejo S, Jos Á (2017) Development, characterization and cytotoxicity of novel silanemodified clay minerals and nanocomposites intended for food packaging. Appl Clay Sci 138:40-47. https://doi.org/10.1016/j.clay. 2016.12.042

Makkar H (2016) Animal nutrition in a 360-degree view and a framework for future R\&D work: towards sustainable livestock production. Anim Prod Sci 56:1561-1568. https://doi.org/10.1071/AN15265

Makkar HP, Ankers P (2014) Towards sustainable animal diets: a surveybased study. Anim Feed Sci Technol 198:309-322. https://doi.org/ 10.1016/j.anifeedsci.2014.09.018

MambaI B, NyembeI B, Mulaba-Bafubiandi A (2010) The effect of conditioning with $\mathrm{NaCl}, \mathrm{KCl}$ and $\mathrm{HCl}$ on the performance of natural clinoptilolite's removal efficiency of $\mathrm{Cu}^{2+}$ and $\mathrm{Co}^{2+}$ from $\mathrm{Co} / \mathrm{Cu}$ synthetic solutions. Water SA 36:437-444. https://doi.org/10.4314/ wsa.v36i4.58419

Mannaa M, Kim K (2017) Influence of temperature and water activity on deleterious fungi and mycotoxin production during grain storage. Mycobiology 45:240-254. https://doi.org/10.5941/MYCO.2017. 45.4.240

Mascolo N, Summa V, Tateo F (2004) In vivo experimental data on the mobility of hazardous chemical elements from clays. Appl Clay Sci 25:23-28. https://doi.org/10.1016/j.clay.2003.07.001

Michel C, Herzog S, de Capitani C, Burkhardt-Holm P, Pietsch C (2014) Natural mineral particles are cytotoxic to rainbow trout gill epithelial cells in vitro. Plos ONE 9:e100856. https://doi.org/10.1371/journal. pone. 0100856

Monbaliu S, Van Poucke C, Detavernier C, Dumoulin F, Van De Velde M, Schoeters E (2010) Occurrence of mycotoxins in feed as analysed by a multi-mycotoxin LC-MS/MS method. J Agric Food Chem 58:66-71. https://doi.org/10.1021/jf903859z

Moreno-Maroto J, Alonso-Azcárate J (2018) What is clay? A new definition of "clay" based on plasticity and its impact on the most widespread soil classification systems. Appl Clay Sci 161:57-63. https:// doi.org/10.1016/j.clay.2018.04.011

Nazarizadeh H, Pourreza J (2019) Evaluation of three mycotoxin binders to prevent the adverse effects of aflatoxin B1 in growing broilers. $\mathrm{J}$ Appl Anim Res 47:135-139. https://doi.org/10.1080/09712119. 2019.1584106

Nones J, Riella H, Trentin A (2015) Effects of bentonite on different cell types: a brief review. Appl Clay Sci 105-106:225-230. https://doi. org/10.1016/j.clay.2014.12.036

Nones J, Poli A, Trentin AG, Riella HG, Kuhnen NC (2016) Organophilic treatments of bentonite increase the adsorption of aflatoxin B1 and protect stem cells against cellular damage. Colloids Surf B: Biointerfaces 145:555-561. https://doi.org/10.1016/j. colsurfb.2016.05.061

Osselaere A, Devreese M, Watteyn A, Vandenbroucke V, Goossens J, Hautekiet V, Eeckhout M, De Saeger S, De Baere S, De Backer P, Croubels S (2012) Efficacy and safety testing of mycotoxindetoxifying agents in broilers following the European Food Safety Authority guidelines. Poult Sci 91:2046-2054. https://doi.org/10. 3382/ps.2012-02245 
Ostry V, Malir F, Toman J, Grosse Y (2016) Mycotoxins as human carcinogens - the IARC monographs classification. Mycotoxin Res 33: 65-73. https://doi.org/10.1007/s12550-016-0265-7

Pappas A, Tsiplakou E, Georgiadou M, Anagnostopoulos C, Markoglou A, Liapis K, Zervas G (2014) Bentonite binders in the presence of mycotoxins: results of in vitro preliminary tests and an in vivo broiler trial. Appl Clay Sci 99:53-53. https://doi.org/10.1016/j.clay.2014. 06.009

Pappas A, Tsiplakou E, Tsitsigiannis D, Georgiadou M, Iliadi M, Sotirakoglou K, Zervas G (2016) The role of bentonite binders in single or concomitant mycotoxin contamination of chicken diets. $\mathrm{Br}$ Poult Sci 57:551-558. https://doi.org/10.1080/00071668.2016. 1187712

Park S, Seo D, Lee J (2002) Surface modification of montmorillonite on surface acid-base characteristics of clay and thermal stability of epoxy/clay nanocomposites. J Colloid Interface Sci 251:160-165. https://doi.org/10.1006/jcis.2002.8379

Peng W, Marchal J, Van der Poel A (2018) Strategies to prevent and reduce mycotoxins for compound feed manufacturing. Anim Feed Sci Technol 237:129-153. https://doi.org/10.1016/j.anifeedsci. 2018.01.017

Pinotti L, Ottoboni M, Giromini C, Dell'Orto V, Cheli F (2016) Mycotoxin contamination in the EU feed supply chain: a focus on cereal by-products. Toxins 8:45. https://doi.org/10.3390/ toxins 8020045

Pitt J, Miller J (2016) A concise history of mycotoxin research. J Agric Food Chem 65:7021-7033. https://doi.org/10.1021/acs.jafc. $6 \mathrm{~b} 04494$

Prvulović D, Jovanović-Galović A, Stanić B, Popović M, Grubor-Lajšić G (2008) Effects of a clinoptilolite supplement in pig diets on performance and serum parameters. Czech J Animal Sci 52:159-166. https://doi.org/10.17221/2317-CJAS

Pushcharovsky D, Zubkova N, Pekov I (2016) Structural chemistry of silicates: new discoveries and ideas. Struct Chem 27:1593-1603. https://doi.org/10.1007/s11224-016-0750-9

Ralla K, Sohling U, Riechers D, Kasper C, Ruf F, Scheper T (2010) Adsorption and separation of proteins by a smectite clay mineral. Bioprocess Biosyst Eng 33:847-861. https://doi.org/10.1007/ s00449-010-0408-8

Rizzi L, Simioli M, Roncada P, Zaghini A (2003) Aflatoxin B1 and clinoptilolite in feed for laying hens: effects on egg quality, mycotoxin residues in livers, and hepatic mixed-function oxygenase activities. J Food Prot 66:860-865

Rodrigues I, Naehrer K (2012) A three-year survey on the worldwide occurrence of mycotoxins in feedstuffs and feed. Toxins 4:663675. https://doi.org/10.3390/toxins4090663

Roland D (1988) Further studies of effects of sodium aluminosilicate on eggshell quality. Poult Sci 67:577-584. https://doi.org/10.3382/ps. 0670577

Schmidhalter U, Kahr G, Evequoz M, Studer C, Oertli JJ (1994) Adsorption of thiamine (vitamin B1) on soils and clays. Soil Sci Soc Am J 58:1829-1837. https://doi.org/10.2136/sssaj1994. 03615995005800060036x

Schwaller D, Wilkens M, Liesegang A (2016) Zeolite A effect on calcium homeostasis in growing goats. J Anim Sci 94:1576-1586. https:// doi.org/10.2527/jas.2015-9690

Seim G, Ahn C, Bodis M, Luwedde F, Miller D, Hillier S, Tako E, Glahn R, Young S (2013) Bioavailability of iron in geophagic earths and clay minerals, and their effect on dietary iron absorption using an in vitro digestion/Caco-2 cell model. Food Funct 4:1263. https://doi. org/10.1039/C3FO30380B

Shannon T, Ledoux D, Rottinghaus G, Shaw D, Daković A, Marković M (2017) The efficacy of raw and concentrated bentonite clay in reducing the toxic effects of aflatoxin in broiler chicks. Poult Sci 408: 2. https://doi.org/10.3382/ps/pew408
Sharma A, Schmidt B, Frandsen H, Jacobsen N, Larsen E, Binderup M (2010) Genotoxicity of unmodified and organo-modified montmorillonite. Mutat Res Genet Toxicol Environ Mutagen 700:18-25. https://doi.org/10.1016/j.mrgentox.2010.04.021

Shryock T, Klink P, Readnour R, Tonkinson L (1994) Effect of bentonite incorporated in a feed ration with tilmicosin in the prevention of induced Mycoplasma gallisepticum Airsacculitis in broiler chickens. Avian Dis 38:501

Smith A, Panickar K, Urban J, Dawson H (2018) Impact of micronutrients on the immune response of animals. Annu Rev Anim Biosci 6:227-254. https://doi.org/10.1146/annurev-animal022516-022914

Sobrane Filho S, Junqueira O, Laurentiz A, Filardi R, Rubio M, Duarte K, Laurentiz R (2016) Effects of mycotoxin adsorbents in aflatoxin B 1 - and fumonisin B 1 -contaminated broiler diet on performance and blood metabolite. Rev Bras Zootec 45:250-256

Srinivasan R (2011) Advances in application of natural clay and its composites in removal of biological, organic, and inorganic contaminants from drinking water. Adv Mater Sci Eng 17:1-17. https:// doi.org/10.1155/2011/872531

Streit E, Schwab C, Sulyok M, Naehrer K, Krska R, Schatzmayr G (2013) Multi-mycotoxin screening reveals the occurrence of 139 different secondary metabolites in feed and feed ingredients. Toxins 5:504 523. https://doi.org/10.3390/toxins5030504

Suzanne C, Aboudi M, Marlia M, Hanafiah A, Jalal K (2017) Environmental characteristics of clay and clay-based minerals. Geo Eco Land 1:155-161. https://doi.org/10.1080/24749508. 2017.136112

Sweeney M (1998) Mycotoxin production by Aspergillus, Fusarium and Penicillium species. Int J Food Microbiol 43:141-158. https://doi. org/10.1016/S0168-1605(98)00112-3

Thilsing T, Larsen T, Jørgensen R, Houe H (2007) The effect of dietary calcium and phosphorus supplementation in zeolite-a treated dry cows on periparturient calcium and phosphorus homeostasis. $\mathrm{J}$ Veterinary Med Ser A 54:82-91. https://doi.org/10.1111/j.14390442.2007.00887.x

Thimm N, Schwaighofer B, Ottner F, Fröschl H, Greifenender S, Binder E (2001) Adsorption of mycotoxins. Mycotoxin Res 17:219-223. https://doi.org/10.1007/BF03036440

Toprak NN, Yilmaz A, Öztürk E, Yigit O, Cedden F (2016) Effect of micronized zeolite addition to lamb concentrate feeds on growth performance and some blood chemistry and metabolites. S Afr J Anim Sci 46:313-320. https://doi.org/10.4314/sajas.v46i3.11

Utlu N, Celebi S, Yücel O (2007) The effects of natural zeolite supplementation to diet on serum element concentrations in laying hens. Rev Med Vet 158:598-602

Verma N, Moore E, Blau W, Volkov Y, Ramesh Babu P (2012) Cytotoxicity evaluation of nanoclays in human epithelial cell line A549 using high content screening and real-time impedance analysis. J Nanopart Res 14. https://doi.org/10.1007/s11051-012-1137-5

Vila-Donat P, Marín S, Sanchis V, Ramos A (2018) A review of the mycotoxin adsorbing agents, with an emphasis on their multibinding capacity, for animal feed decontamination. Food Chem Toxicol 114:46-259. https://doi.org/10.1016/j.fct.2018.02.044

Wang A, Freeman J, Jolliff B (2015) Understanding the Raman spectral features of phyllosilicates. J Raman Spectrosc 46:829-845. https:// doi.org/10.1002/jrs.4680

Wang G, Miao Y, Sun Z, Zheng S (2018) Simultaneous adsorption of aflatoxin $\mathrm{B} 1$ and zearalenone by mono- and di-alkyl cationic surfactants modified montmorillonites. J Colloid Interface Sci 511:67-76. https://doi.org/10.1016/j.jcis.2017.09.074

Watts C, Chen Y, Ledoux D, Broomhead J, Bermudez A, Rottinghaus G (2003) Effects of multiple mycotoxins and a hydrated sodium calcium aluminosilicate in poultry. Int J Poult Sci 2:372-378. https://doi. org/10.3923/ijps.2003.372.378 
Wei J, Wu K, Sun H, Khalil M, Dai J, Liu Y, Liu Q, Zhang N, Qi D, Sun L (2019) A novel modified hydrated sodium calcium aluminosilicate (HSCAS) adsorbent can effectively reduce $\mathrm{T}-2$ toxin-induced toxicity in growth performance, nutrient digestibility, serum biochemistry, and small intestinal morphology in chicks. Toxins 11:199. https://doi.org/10.3390/toxins11040199

Wielogórska E, MacDonald S, Elliott C (2016) A review of the efficacy of mycotoxin detoxifying agents used in feed in light of changing global environment and legislation. World Mycotoxin J 9:419-433. https://doi.org/10.3920/WMJ2015.1919

Yang L, Zhao Z, Deng Y, Zhou Z, Hou J (2014) Toxicity induced by F. poae-contaminated feed and the protective effect of montmorillonite supplementation in broilers. Food Chem Toxicol 74:120-130. https://doi.org/10.1016/j.fct.2014.09.011

Yang W, Chen Y, Cheng Y, Wen C, Zhou Y (2017) Effects of zinc bearing palygorskite supplementation on the growth performance, hepatic mineral content, and antioxidant status of broilers at early age. Asian Australas J Anim Sci 30:1006-1012. https://doi.org/10.5713/ajas. 16.0551

Zain M (2011) Impact of mycotoxins on humans and animals. J Saudi Chem Soc 15:129-144. https://doi.org/10.1016/j.jscs.2010.06.006
Zaki M (2012) Mycotoxins in animals: occurrence, effects, prevention and management. J Toxicol Environ Health Sci 4:13-28. https://doi. org/10.5897/JTEHS11.072

Zhang M, Lu Y, Li X, Chen Q, Lu L, Xing M, Zou H, He J (2010) Studying the cytotoxicity and oxidative stress induced by two kinds of bentonite particles on human B lymphoblast cells in vitro. Chem Biol Interact 183:390-396. https://doi.org/10.1016/j.cbi.2009.11. 023

Zhao H, Mao X, Yu B, He J, Zheng P, Yu J, Luo J, Wang Q, Chen D (2017) Excess of dietary montmorillonite impairs growth performance, liver function, and antioxidant capacity in starter pigs. J Anim Sci 95:2943-2951. https://doi.org/10.2527/jas.2016.1277

Zhu Y, Hassan Y, Watts C, Zhou T (2016) Innovative technologies for the mitigation of mycotoxins in animal feed and ingredients - a review of recent patents. Anim Feed Sci Technol 216:19-29. https://doi.org/ 10.1016/j.anifeedsci.2016.03.030

Publisher's note Springer Nature remains neutral with regard to jurisdictional claims in published maps and institutional affiliations. 